\title{
Synthesis of (-)-Matairesinol, (-)- Enterolactone and (-)-Enterodiol from the Natural Lignan Hydroxymatairesinol.
}

\author{
Patrik Eklund, * Anna Lindholm, J-P Mikkola, Annika Smeds, Reko Lehtilä and \\ Rainer Sjöholm.
}

Department of Organic Chemistry, Åbo Akademi University, Biskopsgatan 8, 20500-FIN, Åbo, Finland. Tel: +35822154502, Fax: +3582215 4866. E-mail: paeklund@abo.fi

\section{Supporting information}

\section{General Experimental:}

All commercially available chemicals were used as supplied by the manufacturers. Hydroxymatairesinol was isolated from Norway spruce knots. Knots were separated, ground and freeze-dried prior to extraction in a soxhlet apparatus. The raw extract obtained with acetone-water (9:1 $\mathrm{v} / \mathrm{v}$ ) after the removal of lipophilic extractives with petroleum ether, was purified by flash chromatography (eluent $\mathrm{CHCl}_{2}$ : EtOH 98:2 v/v) to yield hydroxymatairesinol. Alternatively, knots were extracted with ethanol, K-acetate was added and the HMR-K-acetate adduct was separated by precipitation and filtration to yield the adduct in $>95 \%$ purity (large-scale). The structure of the adduct has not been established. Hovewer, the adduct is easily destroyed by extraction in dichloromethane/water and free HMR is obtained, which indicates a non-covalent complex.

GC analyses were performed on a HP-5890 standard gas chromatograph equipped with a HP-5 column and a FI detector. The samples were silylated using hexamethyldisilazanechlorotrimethylsilane in pyridine, prior to analyses. HRMS were recorded on a ZabSpecETOF system.

${ }^{1} \mathrm{H}$ and ${ }^{13} \mathrm{C}$ spectra were recorded on a JEOL JNM-A500 spectrometer at 500 and $125 \mathrm{MHz}$, respectively. $2 \mathrm{D}$ experiments were recorded using JEOL standard pulse sequences and chemical shifts are reported downfield from tetramethylsilane. The assignments of the ${ }^{1} \mathrm{H}$ and ${ }^{13} \mathrm{C}$ signals were based on homonuclear and heteronuclear direct and long-range correlation spectroscopy (COSY, HMQC, HMBC, COLOC).

Optical rotations were measured with a Perkin Elmer 241 digital polarimeter, using a $1 \mathrm{dm}, 1 \mathrm{ml}$ cell. Analytical TLC was carried out on pre-coated aluminium based sheets (Merk $60 \mathrm{~F}_{254}$ ). Chiral HPLCMS was performed on a PE-Sciex API 3000 instrument equipped with a CHIRALCEL OD-R analytical column $(0.46 \times 25 \mathrm{~cm})$ using multiple reaction monitoring techniques (MRM).

\section{Experimental procedures:}

\section{Hydrogenolysis of hydroxymatairesinol (1) to matairesinol (2) at athmospheric pressure.}

The hydrogenolysis was performed in a $50 \mathrm{~mL}$ double necked round bottom flask with vigorous magnetic stirring. $515 \mathrm{mg}$ of Pd-C $10 \%(0.48 \mathrm{mmol})$ as a slurry in $4 \mathrm{~mL}$ of 1,2-dichloroethane was activated with $\mathrm{H}_{2}$-gas (1 bar) at $\mathrm{rt}$. for $1 \mathrm{~h} 10 \mathrm{~min}$. Hydroxymatairesinol (1) (1.5 g as an app. 3:1 mixture of the diastereomers) was added to the slurry in $8 \mathrm{ml}$ of 1,2-dichloroethane. The mixture was heated on an oil bath, and the temperature was kept between 40 and $60{ }^{\circ} \mathrm{C}$ for $17 \mathrm{~h}$ under hydrogen. Then $10 \mathrm{mg}$ of Pd-C 10\% (0.9 mmol) was added and the reaction was continued for $1 \mathrm{~h} 45 \mathrm{~min}$ at 50 ${ }^{\circ} \mathrm{C}$. The reaction mixture was filtered through two filter papers, S\&S 589 and Whatman 1-PS with $\mathrm{CH}_{2} \mathrm{Cl}_{2}$. The product was purified by column chromatography (silica gel) using toluene/EtOAc from 100:0 to 170:40 as eluent. After evaporation of the solvents and drying in vacuo, $327 \mathrm{mg}(69 \%)$ of 2 was obtained. 
$[\alpha]_{D}^{24}=-36.9^{\circ}\left(c=3.33\right.$ in THF, Lab Scan 99.8\%), in literature $[\alpha]^{20}{ }_{D}=-42.2^{\circ}(c=1$ in acetone $)$ Barton, G. M.; Gardner, J. A. F J. Org. Chem. 1962, 27, 322-323.

All other spectroscopic and spectrometric data in accordance with previously reported, Fonseca, S. F.; Campello, J. P.; Barata, L. E. S.; Rúveda E. A. Phytochemistry 1978, 17, 499-502. Lin, R. C.; Skaltsounis, A-L.; Seguin, E.; Tillequin, F.; Koch, M. Planta Med. 1994, 60, 2, 168.

HRMS (EI) $\mathrm{m} / \mathrm{z}$ calculated for $\mathrm{C}_{20} \mathrm{H}_{22} \mathrm{O}_{6}\left(\mathrm{M}^{+}\right) 358.1417$ found 358.1419 ; EIMS m/z $358\left(62 \%, \mathrm{M}^{+}\right)$, 221 (7), 164 (6), 137 (100), 122 (8) ${ }^{\mathbf{1}} \mathbf{H}$ NMR (500 MHz, CDCl $) \delta 2.39$ (1H, m, H-8), 2.43 (1H, dd, overlapping, H-7’a) 2.49 (1H, m, H-8), 2.52 (1H, dd, J = 13.5, 6.6 Hz, H-7’b), 2.80 (1H, dd, J = 14.1, $7.1 \mathrm{~Hz}, \mathrm{H}-7 \mathrm{a}), 2.88$ (1H, dd, J = 14.1, $5.2 \mathrm{~Hz}, \mathrm{H}-7 \mathrm{~b}), 3.73$ (3H, s, OMe'), 3.74 (3H, s, OMe), $3.81(1 \mathrm{H}$, dd, J = 9.2, 7.2 Hz, H-9’a), 4.07 (1H, dd, J = 9.2, 7.3 Hz, H-9`b), 5.55 (1H, s, OH'), $5.56(1 \mathrm{H}, \mathrm{s}, \mathrm{OH})$, $6.34\left(1 \mathrm{H}, \mathrm{d}, \mathrm{J}=2.0 \mathrm{~Hz}, \mathrm{H}-2^{\prime}\right), 6.44(1 \mathrm{H}, \mathrm{dd}, \mathrm{J}=2.0,8.0 \mathrm{~Hz}, \mathrm{H}-6$ ' $), 6.53(1 \mathrm{H}, \mathrm{dd}, \mathrm{J}=2.0,7.8 \mathrm{~Hz}, \mathrm{H}-\mathrm{H}-$ 6), $6.55(1 \mathrm{H}, \mathrm{d}, \mathrm{J}=2.0 \mathrm{~Hz}, \mathrm{H}-2), 6.73\left(1 \mathrm{H}, \mathrm{d}, \mathrm{J}=8.0 \mathrm{~Hz}, \mathrm{H}-5^{\prime}\right), 6.75(1 \mathrm{H}, \mathrm{d}, \mathrm{J}=7.8 \mathrm{~Hz}, \mathrm{H}-5) ;{ }^{13} \mathbf{C}$ NMR $\left(500 \mathrm{MHz}, \mathrm{CDCl}_{3}\right) \delta 34.62\left(\mathrm{C}^{-7}\right), 38.32\left(\mathrm{C}^{-} 7^{\prime}\right), 41.04\left(\mathrm{C}^{\prime} 8^{\prime}\right), 46.59(\mathrm{C}-8), 55.85$ (2 x OMe), 71.37 (C-9'), 111.07 (C-2'), 111.61 (C-2), 114.17 (C-5'), 114.47 (C-5), 121.35 (C-6'), 122.11 (C-6), 129.59 (C-1'), 129.83 (C-1), 144.46 (C-4'), 145.59 (C-4), 146.68 (C-3'), 146.78 (C-3), 178.85 (C-9).

\section{Pressurized hydrogenolysis of hydroxymatairesinol.}

An isothermal, laboratory scale, stainless steel pressure autoclave (with baffles) having an internal diameter of $64 \mathrm{~mm}$ and a length of $103 \mathrm{~mm}$ was filled with $150 \mathrm{ml}$ of 1,2-dichloroethane. Hydroxymatairesinol (1.5 g) and Pd-C $10 \%(0.3 \mathrm{~g})$ catalyst were added to the reaction vessel. The reaction mixture was warmed with an electrical coil to $50{ }^{\circ} \mathrm{C}$ while it was flushed with $\mathrm{N}_{2}(99,999 \%$ pure, AGA OYj) to remove oxygen from the vessel (equipped with a cooling coil and temperature controller). The reaction mixture was stirred first at $500 \mathrm{rpm}$ and after the temperature had reached 36

${ }^{\circ} \mathrm{C}$, at $1000 \mathrm{rpm}$. When the reaction mixture reached a temperature of $50{ }^{\circ} \mathrm{C}, \mathrm{H}_{2}(99,999 \%$ pure, AGA $\mathrm{OYj}$ ) was introduced to the reaction mixture followed by $\mathrm{N}_{2}$ to make sure that all oxygen had been removed from the reaction mixture. After this the hydrogenolysis was performed by introducing again $\mathrm{H}_{2}$ to the vessel. The pressure was adjusted to 8 bar. The reaction was allowed to proceed for 240 minutes after which the reaction mixture was filtered through a filter paper. According to GC-MS (HP5890 Series II Gas chromatograph equipped with a HP-5971A-mass selective detector; column $30 \mathrm{~m} \mathrm{x}$ $0.25 \mathrm{~mm} \times 0.25 \mu \mathrm{m}$ HP-1MS) the conversion of 1 to 2 was quantitative.

\section{High pressure hydrogenolysis of HMR-KAc adduct.}

\section{Example 1}

An isothermal, laboratory scale, stainless steel pressure autoclave (no baffles, equipped with a standard propeller stirrer) having an internal diameter of $64 \mathrm{~mm}$ and a length of $103 \mathrm{~mm}$ was filled with $100 \mathrm{~g}$ of EtOH (Ethanol Aa, purity $96 \%$-vol, Primalco Oy) in which $15 \mathrm{~g}$ of HMR K-acetate adduct (used as such - not dried) was dissolved on a heat plate. $9.8 \mathrm{~g}$ of washed (deionized water and ethanol). ( Mopromoted Raney nickel (Acticat, Catalloy Ltd) catalyst was inserted into the reactor vessel together with the reaction mixture and heating was switched on. The mixture was flushed with hydrogen ( $99.999 \%$ pure, AGA Oyj) for 2 minutes to remove oxygen from the vessel. During the heating period the stirrer was not engaged. The heating was swiched on and the reactor reached the desired reaction temperature of $130{ }^{\circ} \mathrm{C}(403 \mathrm{~K})$ in $9 \mathrm{~min}$. The stirrer was switched on $(1100 \mathrm{rpm})$ and this was considered the initial start of the hydrogenation batch. The pressure was adjusted to 700 PSI (approx. 50 bar).

The reaction was allowed to proceed for approximately $300 \mathrm{~min}$ and during the reaction small amounts of samples were withdrawn from the reaction mixture for later analysis by means of GC. The samples (a few milliliters) were obtained through a $5 \mu \mathrm{m}$ metallic sinter filter by cracking a sample valve, immediately wrapped into an aluminium folio to protect them from light exposure and transferred to a freezer $\left(-20^{\circ} \mathrm{C}, 253 \mathrm{~K}\right)$. The optimal yield of matairesinol $95.4 \mathrm{wt}-\%$ was reached in $161 \mathrm{~min}$. The initial concentration of $0.61 \mathrm{wt}-\%$ (some reaction takes place immediately since active Ra-Ni catalyst contains chemisorbed hydrogen) increased to the earlier mentioned $95.4 \mathrm{wt}-\%$, whereas the initial HMR content of $93.9 \mathrm{wt}-\%$ (allo-HMR $9.9 \mathrm{wt}-\%$, HMR $84 \mathrm{wt}-\%$ ) was reduced to $5.5 \mathrm{wt}-\%$ (allo-HMR 3.1 and HMR 2.4 wt- $\%$, respectively). Minor amounts of the following by-products were detected 
during the cause of the reaction: 7-hydroxy secoisolariciresinol, secoisolariciresinol, liovil, conidendric acid, conidendrin and lariciresinol.

\section{Example 2}

An isothermal, laboratory scale, stainless steel pressure autoclave (no baffles, equipped with a highly efficient turbine gas disperser coupled to a traditional propeller stirrer) having an internal diameter of $64 \mathrm{~mm}$ and a length of $103 \mathrm{~mm}$ was filled with $100 \mathrm{~g}$ of EtOH (Ethanol Aa, purity $96 \%$-vol, Primalco Oy) in which $10 \mathrm{~g}$ of HMR-Kac adduct (used as such - not dried) was dissolved on a heat plate. $1 \mathrm{~g}$ of $\mathrm{Pd} / \mathrm{C}$ (Palladium on active carbon, Acros Ltd) catalyst that was used in an earlier experiment was inserted into the reactor vessel together with the reaction mixture. The mixture was flushed with hydrogen (99.999\% pure, AGA Oyj) for 2 minutes to remove oxygen from the vessel. During the heating period $(10 \mathrm{~min}$.) the stirrer was not engaged. After the reactor reached the desired reaction temperature of $100{ }^{\circ} \mathrm{C}$ the stirrer was switched on $(1100 \mathrm{rpm})$ and this was considered the initial start of the hydrogenation batch. The pressure was adjusted to approx. 30 bar.

The reaction was allowed to proceed for 295 minutes and no samples (except a few $\mathrm{ml}$ in the beginning and at the end of the batch) were withdrawn from the reaction mixture.

After 295 minutes the contents of the reaction vessel were emptied, the catalyst was filtrated off by means of vacuum filtration through a filter paper. The solvent was removed under reduced pressure and residue was redissolved in $\mathrm{CH}_{2} \mathrm{Cl}_{2}$ and washed with water to remove $\mathrm{K}$-acetate. The organic phase was dried over $\mathrm{NaSO}_{4}$, concentrated and chromatographed on a short silica column using $\mathrm{CHCl}_{3}: \mathrm{MeOH}$ $(92: 2 \mathrm{v} / \mathrm{v})$ as eluent, yielding $5.55 \mathrm{~g}$ (73\%, calculated from the undried HMR-KAc adduct of unknown composition ) pure matairesinol after drying in vacuo.

\section{Matairesinyl 4,4’-bistriflate (3)}

To a solution of $1.1 \mathrm{~g}(3 \mathrm{mmol})$ matairesinol (2) in dry $\mathrm{CH}_{2} \mathrm{Cl}_{2}(15 \mathrm{ml})$ lutidine $(2.6 \mathrm{~g})$ was added. The reaction mixture was mainatined at $0{ }^{\circ} \mathrm{C}$ under argon and $1.2 \mathrm{ml}(7.2 \mathrm{mmol})$ of triflic anhydride was added slowly to the mixture. After $48 \mathrm{hrs}, 200 \mathrm{ml}$ of dichloromethane was added and the mixture was extracted $(5 \times 100 \mathrm{ml})$ with distilled water. The organic phase was dried over $\mathrm{Na}_{2} \mathrm{SO}_{4}$, filtered and the solvent was removed under reduced pressure. The product was purified by flash column chromatography, using ethyl acetate:petroleum ether as eluent $(1: 3 \mathrm{v} / \mathrm{v})$ to afford $1.6 \mathrm{~g}(88 \%)$ of pure matairesinyl 4,4'-bis triflate (3).

HRMS (EI) $\mathrm{m} / z$ calculated for $\mathrm{C}_{22} \mathrm{H}_{20} \mathrm{~F}_{6} \mathrm{O}_{10} \mathrm{~S}_{2}\left(\mathrm{M}^{+}\right) 622.0402$ found 622.0403 ; EIMS m/z $622(63 \%$, $\mathbf{M}^{+}$), 489 (100), 269 (22), 219 (6), 205 (13), 178 (22), 163 (11), 137 (44); ${ }^{1} \mathbf{H}$ NMR (500 MHz, CDCl NM $\delta 2.48\left(1 \mathrm{H}, \mathrm{m}, \mathrm{H}-8^{\prime}\right), 2.62(1 \mathrm{H}, \mathrm{m}, \mathrm{H}-8), 2.69$ (1H, dd, $\left.J=13.5,7.3 \mathrm{~Hz}, \mathrm{H}-7^{\prime} \mathrm{a}\right), 2.70$ (1H, dd, $J$ $=13.5,7.0 \mathrm{~Hz}, \mathrm{H}-7 ` \mathrm{~b}), 2.99(1 \mathrm{H}, \mathrm{d}, J=6.7 \mathrm{~Hz}, \mathrm{H}-7), 3.85\left(1 \mathrm{H}, \mathrm{s}, \mathrm{CH}_{3}-\mathrm{O}^{\prime}\right), 3.86\left(1 \mathrm{H}, \mathrm{s}, \mathrm{CH}_{3}-\mathrm{O}\right), 3.92$ $\left(1 \mathrm{H}, \mathrm{dd}, J=9.1,7.9 \mathrm{~Hz}, \mathrm{H}-9^{\prime} \mathrm{a}\right), 4.23\left(1 \mathrm{H}, \mathrm{dd}, J=9.1,7.5 \mathrm{~Hz}, \mathrm{H}-9{ }^{\prime} \mathrm{b}\right), 6.60(2 \mathrm{H}, 2 \mathrm{x} \mathrm{dd}, J=8.2,2.1 \mathrm{~Hz}$, H -6, H-6'), 6.64 (1H, d, J =2.0 Hz, H -2'), 6.85 (1H, d J =2.0 Hz, H -2), $7.11(1 \mathrm{H}, \mathrm{d} J=8.2 \mathrm{~Hz}, \mathrm{H}-$ $\left.5^{\prime}\right), 7.13(1 \mathrm{H}, \mathrm{d} J=8.2 \mathrm{~Hz}, \mathrm{H}-5) .{ }^{13} \mathbf{C}$ NMR (500 MHz, $\left.\mathrm{CDCl}_{3}\right) \delta 34.53(\mathrm{C}-7), 38.49$ (C-7'), 40.87(C$\left.8^{\prime}\right), 46.40$ (C-8), $55.18\left(\mathrm{CH}_{3}-\mathrm{O}^{\prime}\right), 55.26\left(\mathrm{CH}_{3}-\mathrm{O}\right), 70.96$ (C-9'), 113.37 (C-2'), $114.04(\mathrm{C}-2), 118.75$ (two d, $J=332.1 \mathrm{~Hz}, 2 \mathrm{x} \mathrm{CF}_{3}$ ), 120.64 (C-6'), 121.39 (C-6), 122.46 (C-5'), 122.82 (C-5), 139.28 (C-1'), 139.42 (C-1), 151.62 (2C, C-4,4'), 177.81 (C-9).

\section{3,3'-dimethylenterolactone (4)}

Matairesinyl 4,4-bistriflate (3) (0.902 g, 1,45 mmol) was dissolved in DMF (4 ml) and triethylamine $(0.9 \mathrm{ml})$ was added. To the mixture, stirred under argon at $85^{\circ} \mathrm{C}$ was added $90 \mathrm{mg}(0.22 \mathrm{mmol})$ of $1,3-$ bis(diphenylphosphino)propane and $54 \mathrm{mg}(0.09 \mathrm{mmol}) \mathrm{PdCl}_{2}\left(\mathrm{PPh}_{3}\right)_{2}$. Finally formic acid (9 drops) was added. After 21 hours, $70 \mathrm{ml}$ dichloromethane and $70 \mathrm{ml}$ water were addded. The organic phase was washed with $10 \% \mathrm{HCl}$ solution $(6 \times 45 \mathrm{ml})$ and then with $45 \mathrm{ml}$ saturated $\mathrm{NaCl}$ solution. The organic phase was dried over $\mathrm{Na}_{2} \mathrm{SO}_{4}$ and the solvent was removed under reduced pressure. The residue was purified by column chromatography, to yield $0.401 \mathrm{~g}(85 \%)$ of 3,3'-dimethylenterolactone (4) in 93\% purity (GC-MS).

HRMS (EI) $m / z$ calculated for $\mathrm{C}_{20} \mathrm{H}_{22} \mathrm{O}_{4}\left(\mathrm{M}^{+}\right) 326.1518$ found 326.1521 ; EIMS m/z $326\left(75 \%, \mathrm{M}^{+}\right)$, 205 (17), 159 (9), 147 (17), 122 (100), 91 (13); ${ }^{1} \mathbf{H}$ NMR (500 MHz, acetone- $\left.d_{6}\right) \delta 2.57$ (1H, m, C-8'), 2.58 (1H, m, H-7’a), 2.67 (1H, m, H-7’a ), 2.69 (1H, m, C-8), 2.91 (1H, dd, J = 13.8, 7.1 Hz, H-7), 3.01 
$(1 \mathrm{H}, \mathrm{dd}, J=13.8,5.4 \mathrm{~Hz}, \mathrm{H}-7), 3.76\left(1 \mathrm{H}, \mathrm{s}, \mathrm{CH}_{3}-\mathrm{O}^{\prime}\right), 3.77\left(1 \mathrm{H}, \mathrm{s}, \mathrm{CH}_{3}-\mathrm{O}\right), 3.90(1 \mathrm{H}, \mathrm{dd}, J=9.1,8.0$ Hz , H-9`a), 4.10 (1H, dd, $J=9.1,7.3 \mathrm{~Hz}, \mathrm{H}-9$ ’ b), 6.63 (1H, dd, $J=2.5,1.6 \mathrm{~Hz}, \mathrm{H}-2^{\prime}$ ), 6.66 (1H, ddd, $\left.J=8.1,1.6,1.0 \mathrm{~Hz}, \mathrm{H}-6^{\prime}\right), 6.75$ (1H, ddd, $J=8.1,2.5,1.0 \mathrm{~Hz}, \mathrm{H}-4$ '), 6.76-6.81 (3H, H-2, H-4, H-6, overlapping), 7.17 $\left(1 \mathrm{H}, \mathrm{dd}, J=8.4,7.6 \mathrm{~Hz}, \mathrm{H}-5^{\prime}\right), 7.20(1 \mathrm{H}, \mathrm{dd}, J=8.7,7.5 \mathrm{~Hz}, \mathrm{H}-5) .{ }^{13} \mathbf{C}$ NMR $(500$

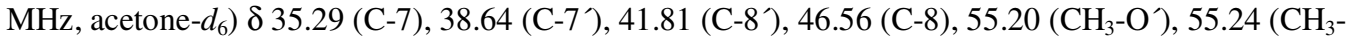
O), 71.34 (C-9'), 112.44 (C-4'), 112.65 (C-4), 114.80 (C-2'), 115.46 (C-2), 121.36 (C-6'), 122.11 (C6), 129.92 (C-5), 130.02 (C-5') 140.28 (C-1), 140.67 (C-1'), 160.43 (C-3 or C-3'), 160.46 (C-3 or C3), 178.53 (C-9).

\section{(-)-Enterolactone (5)}

3,3'-dimetylenterolactone 4 (400 mg, $1.227 \mathrm{mmol}$ ) was dissolved in $20 \mathrm{ml} \mathrm{dry} \mathrm{CH}_{2} \mathrm{Cl}_{2}$. The solution was rapidly stirred and cooled to $-10{ }^{\circ} \mathrm{C}$ under argon. Then $\mathrm{BBr}_{3}(3.5$ eqv., $4.3 \mathrm{mmol}, 4.3 \mathrm{ml}$ of $1 \mathrm{M}$ $\mathrm{BBr}_{3}$ in $\mathrm{CH}_{2} \mathrm{Cl}_{2}$ ) was added dropwise over a period of $15 \mathrm{~min}$. The mixture was stirred at $-10{ }^{\circ} \mathrm{C}$ for 6 $\mathrm{h}$ and then allowed to warm to room temperature. After totally $18 \mathrm{~h}, 40 \mathrm{ml}$ water was added and the mixture was extracted with $\mathrm{CH}_{2} \mathrm{Cl}_{2}(2 \times 30 \mathrm{ml})$. The organic phase was washed with $20 \mathrm{ml}$ saturated $\mathrm{NaCl}$ solution, dried over $\mathrm{Na}_{2} \mathrm{SO}_{4}$ and finally the solvent was removed under reduced pressure. The residue was chromatographed on a short silica column using $\mathrm{CHCl}_{3}: \mathrm{MeOH}(99: 1 \mathrm{v} / \mathrm{v})$ as eluent to yield $291 \mathrm{mg}(79 \%)$ of (-)-enterolactone (5) as a colourless powder after drying in vacuo. Purity $>97$ $\%(\mathrm{GC})$.

$[\alpha]_{D}^{24}=-39.4^{\circ}\left(\mathrm{c}=0.52\right.$ in $\left.\mathrm{CHCl}_{3}\right)$, in literature: $[\alpha]_{\mathrm{D}}^{24}=-38.4^{\circ}\left(\mathrm{c}=1\right.$ in $\left.\mathrm{CHCl}_{3}\right)$, Stitch, R. S. et al. Nature, 1980, 287, 738-740., $[\alpha]_{\mathrm{D}}^{19}=-40.3^{\circ}\left(\mathrm{c}=0.553\right.$ in $\left.\mathrm{CHCl}_{3}\right)$ Van Oeveren, A.; Jansen, J. F. G. A.; Feringa, B. L. J. Org. Chem. 1994, 59, 5999., [ $\alpha]^{24}{ }_{\mathrm{D}}=-38.3^{\circ}\left(\mathrm{c}=0.29\right.$ in $\left.\mathrm{CHCl}_{3}\right)$, Sibi, M. P.; Liu, P.; Johnson, M. D. Can. J. Chem. 2000, 78, 133-138.

HRMS (EI) $\mathrm{m} / \mathrm{z}$ calculated for $\mathrm{C}_{18} \mathrm{H}_{18} \mathrm{O}_{4}\left(\mathrm{M}^{+}\right) 298.1205$ found 298.1200; EIMS m/z $298\left(37 \%, \mathbf{M}^{+}\right)$, 191 (20), 145 (14), 133 (17), 108 (100), 77 (15); ${ }^{1} \mathbf{H}$ NMR (500 MHz, acetone- $\left.d_{6}\right) \delta 2.51(1 \mathrm{H}, \mathrm{m}, \mathrm{H}-$ 7'), 2.55 (1H, m, H-8'), 2.67 (1H, m, H-8), 2.69 (1H, m, H-7'), 2.88 (1H, dd $J=13.8,6.7 \mathrm{~Hz}, \mathrm{H}-7 \mathrm{a})$, 2.97(1H, dd $J=13.8,5.4 \mathrm{~Hz}, \mathrm{H}-7 \mathrm{~b}), 3.88\left(1 \mathrm{H}, \mathrm{t} J=8.9 \mathrm{~Hz}, \mathrm{H}-9{ }^{\prime} \mathrm{a}\right), 4.04(1 \mathrm{H}, \mathrm{dd} J=8.9,7.2 \mathrm{~Hz}, \mathrm{H}-$ 9’b), 6.60 (1H, dt $J=7.5,1.6 \mathrm{~Hz}$, complex, H-6'), 6.63 (1H, dd $\left.J=1.6,2.5 \mathrm{~Hz}, \mathrm{H}-2^{\prime}\right), 6.68$ (1H, ddd $J$ $\left.=8.1,2.5,1.0 \mathrm{~Hz}, \mathrm{H}-4^{\prime}\right), 6.71(1 \mathrm{H}$, ddd, overlapping, $\mathrm{H}-4), 6.72(1 \mathrm{H}, \mathrm{m}$, overlapping, $\mathrm{H}-6), 6.78(1 \mathrm{H}, \mathrm{t}$ $J=2.1 \mathrm{~Hz}, \mathrm{H}-2), 7.09\left(1 \mathrm{H}, \mathrm{t} J=7.7 \mathrm{~Hz}, \mathrm{H}-5^{\prime}\right), 7.13(1 \mathrm{H}, \mathrm{t} J=7.7 \mathrm{~Hz}, \mathrm{H}-5), 8.20\left(1 \mathrm{H}, \mathrm{s}, 3^{\prime}-\mathrm{OH}\right), 8.24$ $(1 \mathrm{H}, \mathrm{s}, 3-\mathrm{OH}) .{ }^{13} \mathrm{C}$ NMR $\left(500 \mathrm{MHz}\right.$, acetone- $\left.d_{6}\right) \delta 35.30(\mathrm{C}-7), 38.68\left(\mathrm{C}-7^{\prime}\right), 42.14\left(\mathrm{C}-8^{\prime}\right), 46.79(\mathrm{C}-$ 8), 71.43 (C-9'), 114.26 (C-4'), 114.46 (C-4), 116.15 (C-2'), 117.11(C-2), 120.61 (C-6'), 121.45 (C-6), 130.26 (C-5), 130.36 (C-5), 140.82 (C-1), 141.30 (C-1'), 158.42 (C-3 and C-3), 178.66 (C-9).

\section{(-)-Enterodiol (6)}

(-)-Enterolactone $(230 \mathrm{mg}, 0.772 \mathrm{mmol})$ was dissolved in $20 \mathrm{ml}$ dry THF. To the solution $\mathrm{LiAlH}_{4}(3$ eqv., $2.31 \mathrm{mmol}, 87.8 \mathrm{mg}$ ) was cautiously added in small portions at room temperature. The mixture was stirred at room temperature for $1 \mathrm{~h}$ and then heated to $50{ }^{\circ} \mathrm{C}$ and stirred for $2 \mathrm{~h}$. The reaction was quenched by pouring the mixture onto $50 \mathrm{ml}$ diluted $\mathrm{HCl}$. The mixture was then extracted first with 30 $\mathrm{ml} \mathrm{EtOAc}$ and then with $50 \mathrm{ml}$ diethylether and finally with $30 \mathrm{ml} \mathrm{CH}_{2} \mathrm{Cl}_{2}$. During the extraction the water phase was saturated with $\mathrm{NaCl}$. The organic phase was dried over $\mathrm{Na}_{2} \mathrm{SO}_{4}$ and the solvents were removed under reduced pressure. The residue was chromatographed on a silica column using EtOAc:Petroleum ether (2:1 v/v) as eluent to yield (-)-enterodiol (6), which upon drying in vacuo afforded $165 \mathrm{mg}(71 \%)$ of a colourless powder, slowly turning into a colourless gum. Purity $>98 \%$ (GC).

$[\alpha]_{\mathrm{D}}^{23}=-15.2^{\circ}(\mathrm{c}=1$ in EtOH $)$, in literature: $[\alpha]_{\mathrm{D}}^{23}=-13.2^{\circ}(\mathrm{c}=1$ in EtOH $)$ Van Oeveren, A.; Jansen, J. F. G. A and Feringa, B. L. J. Org. Chem. 1994, 59, 5999.

HRMS (EI) $m / z$ calculated for $\mathrm{C}_{18} \mathrm{H}_{22} \mathrm{O}_{4}\left(\mathrm{M}^{+}\right) 302.15181$ found 302.1524 ; EIMS m/z $302\left(7 \%, \mathrm{M}^{+}\right)$, 284 (16), 266 (4), 177 (17), 159 (30), 145 (14), 133 (16), 120 (7), 108 (100); ${ }^{1} \mathbf{H}$ NMR (500 MHz, acetone- $\left.d_{6}\right) \delta 1.64(2 \mathrm{H}, \mathrm{m}, \mathrm{H}-8), 2.68(4 \mathrm{H}, \mathrm{m}, \mathrm{H}-7), 3.35(2 \mathrm{H}, \mathrm{dd} J=4.4,12.4 \mathrm{~Hz}, \mathrm{H}-9 \mathrm{a}), 3.78(2 \mathrm{H}, \mathrm{dd}$, $J=1.8,12.4 \mathrm{~Hz}, \mathrm{H}-9 \mathrm{~b}), 6.63(2 \mathrm{H}, \mathrm{ddd}, J=7.5,1.1,1.5 \mathrm{~Hz}, \mathrm{H}-6), 6.66$ (2H, ddd, $J=8.0,1.1,2.5 \mathrm{~Hz}$, H-4), 6.68 (2H, ddd , complex, $J=2.5,0.5,1.5 \mathrm{~Hz}, \mathrm{H}-2), 7.07$ (2H, ddd, $J=8.0,7.57,0.5 \mathrm{~Hz}, \mathrm{H}-5)$; 
${ }^{13}$ C NMR $\left(500 \mathrm{MHz}, \mathrm{C}_{3} \mathrm{D}_{6} \mathrm{O}\right) \delta 38.12$ (C-7), 45.03 (C-8), 61.54 (C-9), 113.66 (C-4), $117.07(\mathrm{C}-2)$, 121.25 (C-6), $130.02(\mathrm{C}-5), 143.31$ (C-1), 158.21 (C-3).

\section{Analyses of human serum and urine samples}

$1,2 \mathrm{ml}$ human serum samples and a $3.8 \mathrm{ml}$ human urine sample (all from different persons, one being an average sample of 3 perons) were enzymatically hydrolysed and solid-phase extracted (Smeds, A. Hakala, K., Development of a sample cleanup and a HPLC-MS/MS method for the Determination of Lignans in Human Plasma, submitted to $J$. of. Chromatography). The enantiomeric composition was analyzed by chiral HPLC-ESI-MS/MS using a Micromass Quatro Micro, triple quadropole mass spectrometer. The MRM (multiple reaction monitoring) parent and daughter ion combinations, HPLC eluents and column were the same as described previously. Saarinen, N. M.; Smeds A.; Mäkelä, S.; Ämmälä, J.; Hakala, K.; Pihlava J-M., Ryhänen, E-L.; Sjöholm R.; Santti, R. J. of Chromatography B, 2002, 777, 321-327. 